\title{
HIV as A Cause of Acute Liver Injury
}

Samantha Quon MD, Eric Hsieh MD, FACP*

Department of Medicine, Keck School of Medicine of USC, Los Angeles, CA

*Corresponding Author: Eric Hsieh, MD, FACP, Vice Chair, Educational Affairs, Director, Residency Program Department of Medicine, Keck School of Medicine of USC, Los Angeles, CA.

Received date: November 07, 2020; Accepted date: December 04, 2020; Published date: December 07, 2020

Citation: S Quon, E Hsieh. (2020) HIV as A Cause of Acute Liver Injury. International Journal of Clinical Case Reports and Reviews. 4(5); DOI: $10.31579 / 2690-4861 / 093$

Copyright: (C) 2020 Eric Hsieh, This is an open-access article distributed under the terms of the Creative Commons Attribution License, which permits unrestricted use, distribution, and reproduction in any medium, provided the original author and source are credited.

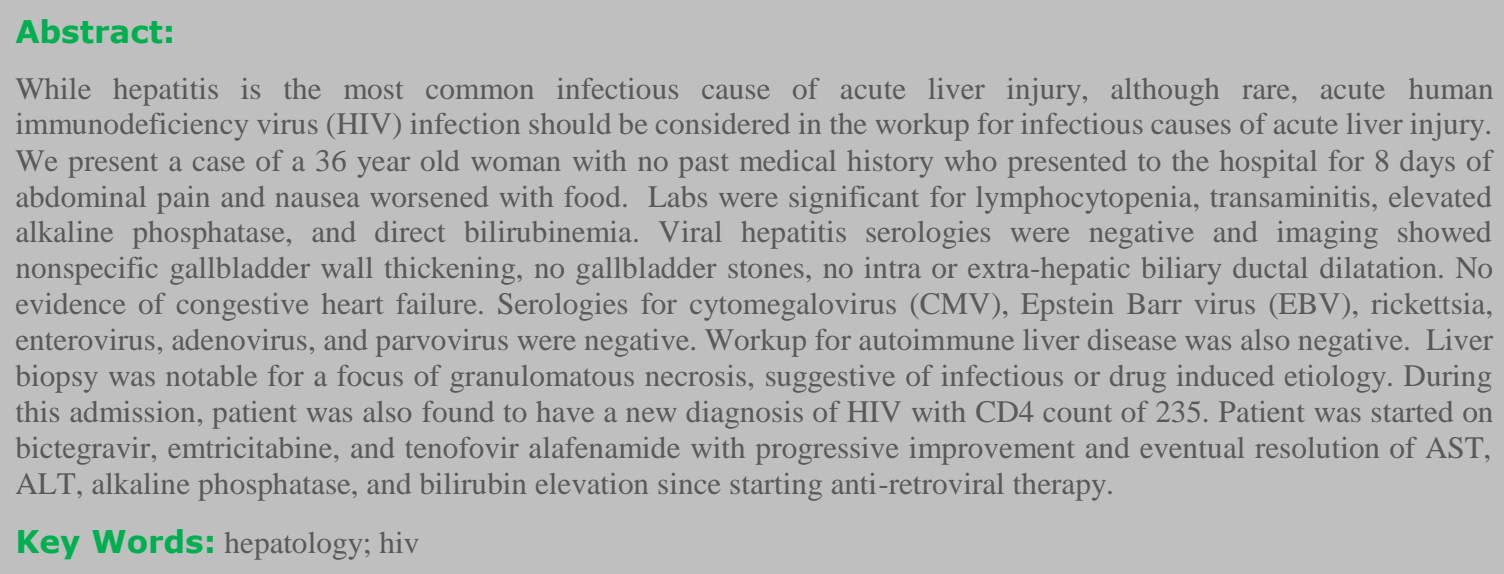

\section{Introduction:}

The differential diagnosis of acute liver injury is broad, including ischemic, infectious, autoimmune, pancreatobiliary, drug induced, and malignant infiltration [1]. While hepatitis is the most common infectious cause of acute liver injury, acute human immunodeficiency virus (HIV) can also cause acute liver injury. Elevated liver enzymes in the setting of $\mathrm{HIV}$ is usually attributed to co-infection with hepatitis B and C, side effect of anti-retroviral medications, or opportunistic infections. However, acute liver injury can also be the result of direct toxicity of HIV $[2,3]$. This is supported by evidence of HIV compartmentalization in liver tissue and identification of liver specific amino acids, which supports the presence of HIV variants replicating in the liver [4, 5]. Furthermore, there is a significant correlation between AST and ALT elevation and HIV viral load in patients without concomitant hepatitis infection or ART use [6]. Acute HIV infection should be considered in the workup for infectious causes of acute liver injury.

\section{Case:}

A 36 year old woman with no past medical history presented to the hospital for 8 days of abdominal pain and nausea worsened with food. Patient was clinically well appearing, and abdominal exam, cardiac, and pulmonary exam was unremarkable. Patient was afebrile, normotensive, no tachycardia, no tachypnea or hypoxia. Abdominal exam was unremarkable. Labs were significant for lymphocytopenia, normocytic anemia, transaminitis, elevated alkaline phosphatase, and elevated bilirubin (Table 1).

\begin{tabular}{|l|l|}
\hline White Blood Cell Count & $3.8 \mathrm{~K} /$ cumm \\
\hline Red Blood Cell Count & $3.47 \mathrm{M} / \mathrm{cumm}$ \\
\hline Hemoglobin & $10.9 \mathrm{~g} / \mathrm{dL}$ \\
\hline Hematocrit & $32.3 \%$ \\
\hline MCV & $92.9 \mathrm{fL}$ \\
\hline Platelets & $114 \mathrm{~K} /$ cumm \\
\hline Absolute Leukocyte Count & $0.7 \mathrm{~K} /$ cumm \\
\hline Absolute Neutrophil Count & $2.7 \mathrm{~K} /$ cumm \\
\hline
\end{tabular}

Table 1: Complete Blood Count

\section{Complete Metabolic Panel}

\begin{tabular}{|l|l|}
\hline Sodium & $137 \mathrm{mmol} / \mathrm{L}$ \\
\hline Potassium & $4.0 \mathrm{mmol} / \mathrm{L}$ \\
\hline Chloride & $104 \mathrm{mmol} / \mathrm{L}$ \\
\hline Bicarbonate & $24 \mathrm{mmol} / \mathrm{L}$ \\
\hline Blood Urea Nitrogen & $10 \mathrm{mg} / \mathrm{dL}$ \\
\hline Creatinine & $0.63 \mathrm{mg} / \mathrm{dL}$ \\
\hline Glucose & $105 \mathrm{mg} / \mathrm{dL}$ \\
\hline Alkaline Phosphatase & $926 \mathrm{U} / \mathrm{L}$ \\
\hline Total Protein & $5.3 \mathrm{~g} / \mathrm{dL}$ \\
\hline Albumin & $3.2 \mathrm{~g} / \mathrm{dL}$ \\
\hline AST & $552 \mathrm{U} / \mathrm{L}$ \\
\hline ALT & $325 \mathrm{U} / \mathrm{L}$ \\
\hline Total Bilirubin & $1.6 \mathrm{mg} / \mathrm{dL}$ \\
\hline
\end{tabular}




\section{Coagulation studies}

\begin{tabular}{|l|l|}
\hline PT & $13.1 \mathrm{sec}$ \\
\hline INR & 1.01 \\
\hline
\end{tabular}

Patient denied medications or supplements, alcohol use, smoking, or recreational drug use, and was monogamous with one male partner. Initial workup included negative viral hepatitis serologies and abdominal ultrasound with nonspecific gallbladder wall thickening, pericholecystic edema/trace fluid, no gallbladder stones, no intra or extra-hepatic biliary ductal dilatation. Patient's BMI was 19, hemoglobin A1c 4.9. A transthoracic echocardiogram showed an ejection fraction $60-65 \%$, no diastolic dysfunction, and no valvular abnormalities. Magnetic resonance cholangiopancreatography also showed nonspecific gallbladder wall thickening, small amount of pericholecystic fluid, no gallstones, intra or extra hepatic bile duct dilatation. Workup for infectious causes of acute liver injury, including cytomegalovirus (CMV), Epstein Barr virus (EBV), rickettsia, enterovirus, adenovirus, and parvovirus serologies, was negative. Antinuclear antibody, liver kidney microsome antibody, smooth muscle antibody, and anti-mitochondrial antibody were negative. Ceruloplasmin level was also within normal. Liver biopsy was performed and pathology was notable for a focus of granulomatous necrosis. There was no portal fibrosis, no steatosis or Mallory bodies, no alpha-1antitripsin inclusions, no tumor, normal bile ducts, trace to 1+ iron staining in hepatocytes, and absent to mild-lymphocytic infiltrates. Stains for fungus, acid fast bacilli, and cytomegalovirus on liver biopsy were also negative. As part of workup for nonspecific abdominal pain and nausea in reproductive age female, screening for sexually transmitted infections was also performed. Urine gonorrhea and chlamydia was negative, but HIV antibody/antigen screen and HIV 1 RNA qualitative screen were positive. HIV 1 viral load was greater than ten million, and CD4 count was 235. Patient was started on bictegravir, emtricitabine, and tenofovir alafenamide with progressive improvement and eventual resolution of AST, ALT, alkaline phosphatase, and bilirubin elevation since starting anti-retroviral therapy.

\section{Discussion:}

We present a case of acute HIV infection presenting with nonspecific abdominal pain and elevated liver enzymes in a mixed cholestatic and hepatocellular pattern. Patient had no known medication exposures concerning for drug induced liver injury. Given patient had normal A1c and BMI, there was low suspicion for non-alcoholic fatty liver disease. Patient had normal cardiac function on transthoracic echocardiogram, therefore unlikely to have congestive hepatopathy. Imaging was negative for portal vein thrombosis or obstructive causes of acute liver injury.
Serologies for common infectious causes of liver injury, including hepatitis were negative. Autoantibodies for autoimmune liver disease were also negative. Liver biopsy findings were nonspecific, however findings consistent with alcoholic hepatitis or nonalcoholic fatty liver disease, alpha-1-antitripsin deficiency, malignancy, hemochromatosis, and hemophagocytic lymphohistiocytosis were notably absent. Given nonspecific pathology findings, negative workup for other etiologies, and new diagnosis of HIV, patient was diagnosed with acute liver injury secondary to acute HIV infection. Furthermore, patient had progressive improvement and resolution of transaminitis and alkaline phosphatase elevation correlating with initiation of anti-retroviral therapy.

\section{Conclusion:}

While less common than other causes, HIV is associated with several mechanisms of acute liver injury including toxicity associated with antiretroviral therapy, opportunistic infection, co-infection with hepatitis viruses, and direct injury from HIV. Evaluation for acute HIV infection should be included in the workup for acute liver injury.

\section{References:}

1. Breu AC, Patwardhan VR, Nayor J, Ringwala JN, Devore ZG, Ganatra RB, et al. (2019) A Multicenter Study Into Causes of Severe Acute Liver Injury. Clin Gastroenterol Hepatol.17(6):1201-1203.

2. Price JC, Seaberg EC, Phair JP, Witt MD, Koletar SL, Thio CL. (2016) Brief Report: Highly Active Antiretroviral Therapy Mitigates Liver Disease in HIV Infection. J Acquir Immune Defic Syndr.72(3):319-323.

3. Ganesan M, Poluektova LY, Kharbanda KK, Osna NA. (2018) Liver as a target of human immunodeficiency virus infection. World J Gastroenterol.24(42):4728-4737.

4. Penton PK, Blackard JT. (2014) Analysis of HIV quasispecies suggests compartmentalization in the liver. AIDS Res Hum Retroviruses.30(4):394-402.

5. Blackard JT, Ma G, Martin CM, Rouster SD, Shata MT, Sherman KE. (2011) HIV variability in the liver and evidence of possible compartmentalization. AIDS Res Hum Retroviruses.27(10):11171126.

6. Mata-Marín JA, Gaytán-Martínez J, Grados-Chavarría BH, Fuentes-Allen JL, Arroyo-Anduiza CI, Alfaro-Mejía A. (2009) Correlation between HIV viral load and aminotransferases as liver damage markers in HIV infected naive patients: a concordance cross-sectional study. Virol J.6:181.
This work is licensed under Creative Commons Attribution 4.0 License

To Submit Your Article Click Here: Submit Article

$$
\begin{aligned}
& \text { Ready to submit your research? Choose Auctores and benefit from: } \\
& \text { *ast, convenient online submission } \\
& \text { rigorous peer review by experienced research in your field } \\
& \text { rapid publication on acceptance } \\
& \text { authors retain copyrights } \\
& \text { unique DOI for all articles }
\end{aligned}
$$

At Auctores, research is always in progress.

Learn more www.auctoresonline.org/journals/international-journalof-clinical-case-reports-and-reviews 